\title{
Öğretmenlerin Yaptıkları Meslek Hatalarının Meslekî Öğrenme Bağlamında İncelenmesi
}

\author{
Taner ATMACA \\ Düzce Üniversitesi, Eğitim Fakültesi, Temel Eğitim Bölümü, Düzce \\ taneratmaca@duzce.edu.tr \\ ORCID ID: https://orcid.org/0000-0001-9157-3100
}

Araştırma Makalesi

DOI: $10.31592 /$ aeusbed.673360

Geliş Tarihi: 10.01.2020

Revize Tarihi: 18.03 .2020

Kabul Tarihi: 18.03 .2020

\section{Atıf Bilgisi}

Atmaca, T. (2020). Öğretmenlerin yaptıkları meslek hatalarının meslekî öğrenme bağlamında incelenmesi. Ahi Evran Üniversitesi Sosyal Bilimler Enstitüsü Dergisi, 6(1), 309-326.

\section{ÖZ}

$\mathrm{Bu}$ çalışmanın temel amacı çeşitli kademelerde görev yapan öğretmenlerin meslek hayatlarında yaptıkları farklı türden hataların meslekî gelişim ve öğrenme kapsamında incelenmesidir. Bu bağlamda, çalıştıkları eğitim kademesi, branşları ve kıdemleri birbirinden farklı toplam 38 öğretmenden nitel araştırma yöntemi çerçevesinde veri toplanmıştır. Araştırmada nitel araştırma yöntemlerinden durum çalışması (örnek olay) deseni tercih edilmiştir. Araştırmanın verileri araştırmacı tarafından hazırlanan form aracıllı̆ı ile elde edilmiştir. Formda öğretmenlerin meslek hayatlarında yaptıkları ve kendilerinde iz bırakan, mesleki gelişimlerine katkı sunduğunu düşündükleri olay ya da olayları detaylıca betimleyerek anlatmaları istenmiştir. Araştırma bulguları öğretmenlerin özellikle mesleğin ilk yıllarında pek çok mesleki hata yaptıklarını ve bu hataların daha çok öğrencileri rencide edici türden olduğunu göstermektedir. Ayrıca anlatılarda ve bulgularda, yapılan kimi hataların öğrencilerde uzun süre iz bırakan nitelikte olduğu yer almaktadır. Öğretmenlerin hata yapmalarına neden olan faktörler arasında en çok deneyimsizliğin, okul idaresi ile olan iletişimsizliğin, öğrenciyi, okul çevresini ve aileleri yakından tanımamanın yer aldığı görülmektedir. Ortaya çıkan bulgulara göre öğretmenler yaptıkları hataları mesleki öğrenme çerçevesinde değerlendirmekte ve kendi mesleki gelişimleri doğrultusunda ele almaktadırlar. Özellikle mesleğin ilk yıllarında rastlanan bu hataların önüne geçebilmek için öğretmenlere lisans eğitimi ve adaylık eğitimi yıllarında hataları en aza indirecek nitelikte tecrübeli yönetici, akademisyen ve öğretmenler tarafından rehberlik yapılması isabetli olacaktır.

Anahtar Kelimeler: Mesleki hata, mesleki gelişim, mesleki öğrenme.

\section{Examination of Professional Mistakes Made by Teachers in the Context of Vocational Learning}

\begin{abstract}
The main purpose of this study is to examine the different types of mistakes in the professional life of the teachers working in various levels in terms of professional development and learning. In this context, data were collected in the framework of qualitative research methods from a total of 38 teachers whose education levels, branches and seniorities were different from each other. In the study, case study research pattern of qualitative research methods was preferred. The data of the study was obtained by the researcher. In the form, teachers were asked to describe the events that they made in their professional lives and left traces in their lives, which they thought contributed to their professional development. Research findings show that teachers made many professional mistakes especially in the first years of the profession and these mistakes mostly caused the students to have a breaker characteristic. In addition, the findings show that some of the mistakes made by the students are long-term. Among the factors that cause teachers to make mistakes are mostly inexperience, lack of communication with the school administration, lack of familiarity with students, school environment and families. Also, according to the findings, teachers take the mistakes they made in the framework of professional learning and deal with their professional development. In order to prevent these mistakes, especially during the first years of the profession, it would be appropriate to provide guidance to teachers by experienced administrators, academicians and teachers who are qualified to minimize mistakes in undergraduate and candidate education years.
\end{abstract}

Keywords: Professional mistake, professional development, professional learning.

\section{Giriş}

Uzmanlık gerektiren pek çok meslekte belirli bir yetkinliğe erişinceye kadar insanlar çeşitli mesleki hatalar yapabilmektedir. Bu hatalar, kimi zaman mesleki beceri ve yetkinliğin yetersizliğinden kaynaklı olabileceği gibi kimi zaman da işin kendisinden, kişiden ve çevreden de kaynaklı olabilmektedir. Ancak profesyonellik gerektiren bir iş olarak öğretmenlik mesleğinde yapılan mesleki 
hataların olumsuz etkileri diğer mesleklere göre fazla olabilmektedir. Çünkü bu mesleğin odağında topluma ve hayata hazırlanan insanlar bulunmaktadır. Bu öğrenme yolculuğunda özellikle öğretmenler tarafından yapılan hataların kimisinin telafisi zor etkileri olabilmektedir. Zira öğretmenler bireyin eğitim hayatında en çok etkileşim kurulan, bireyi toplumsallaştıran, pedagojik dönüşümü gerçekleştiren ve insanların hayatında en çok etki ve iz bırakan kişiler olarak kabul edilmektedir (Özer, Gelen, Alkan, Çınar ve Duran, 2016). Bu bağlamda ele alındığında öğretmenlere düşen mesleki sorumluluğun da büyüklüğü daha net görülebilmektedir. Bu sorumluluğu taşıyabilecek kişilerin de pedagojik bilgi ve donanımlarının yeterli olması, kişiliğinin öğretmenlik mesleğine uygun olması, etkili iletişim becerilerini gerçekleştirebiliyor olması, liderlik yönünün güçlü olması, çatışma yönetim becerilerine sahip olması beklenir.

Öğretmenlerin profesyonelce işlerini yürütebilmeleri için mesleki yeterlikleri sağlamış olmaları gerekmektedir. Türkiye'de Millî Eğitim Bakanlığı (MEB) tarafından belirlenen bu yeterlik alanları üç ana başlık ve on bir alt başlık altında Tablo 1'de sunulmuştur:

Tablo 1

Ö̈retmenlik Mesleği Genel Yeterlikleri

\begin{tabular}{|c|c|c|}
\hline A. Meslek Bilgisi & B. Mesleki Beceri & C.Tutum ve Değerler \\
\hline A1. Alan Bilgisi & B1. Eğitim-Öğretimi Planlama & $\begin{array}{l}\text { C1. Milli, Manevi ve Evrensel } \\
\text { Değerler }\end{array}$ \\
\hline $\begin{array}{l}\text { Alanında sorgulayıcı bakış açısını } \\
\text { kapsayacak şekilde ileri düzeyde } \\
\text { kuramsal, metodolojik ve olgusal } \\
\text { bilgiye sahiptir. }\end{array}$ & $\begin{array}{l}\text { Eğitim ve öğretim süreçlerini } \\
\text { etkin bir şekilde planlar. }\end{array}$ & $\begin{array}{l}\text { Milli, manevi ve evrensel değerleri } \\
\text { gözetir. }\end{array}$ \\
\hline A2. Alan Ĕ̈itimi Bilgisi & $\begin{array}{l}\text { B2. Öğrenme Ortamlar } \\
\text { Oluşturma }\end{array}$ & C2. Ö̆grenciye Yaklaşım \\
\hline $\begin{array}{l}\text { Alanının öğretim programına ve } \\
\text { pedagojik alan bilgisine hâkimdir. }\end{array}$ & $\begin{array}{l}\text { Bütün öğrenciler için etkili } \\
\text { öğrenmenin gerçekleşebileceği } \\
\text { sağlıklı ve güvenli öğretim } \\
\text { materyalleri hazırlar. }\end{array}$ & $\begin{array}{c}\text { Öğrencilerin gelişimini } \\
\text { destekleyici tutum sergiler. }\end{array}$ \\
\hline A3. Mevzuat Bilgisi & $\begin{array}{l}\text { B3. Ögretme ve Öğrenme } \\
\text { Süreçlerini Yönetme }\end{array}$ & C3. Illetişim ve İşbirliği \\
\hline \multirow{3}{*}{$\begin{array}{l}\text { Birey ve öğretmen olarak görev, } \\
\text { hak ve sorumluluklarına ilişkin } \\
\text { mevzuata uygun davranır. }\end{array}$} & $\begin{array}{l}\text { Öğretme ve öğrenme sürecini } \\
\text { etkili bir şekilde yürütür. }\end{array}$ & $\begin{array}{l}\text { Öğrenci, meslektaş, aile ve } \\
\text { eğitimin diğer paydaşları ile etkili } \\
\text { iletişim ve işbirliği kurar. }\end{array}$ \\
\hline & B4. Ölçme ve Değerlendirme & C4. Kişisel ve Mesleki Gelişim \\
\hline & $\begin{array}{l}\text { Ölçme ve değerlendirme, } \\
\text { yöntem, teknik ve araçlarını } \\
\text { amacına uygun kullanır }\end{array}$ & $\begin{array}{c}\text { Öz değerlendirme yaparak kişisel } \\
\text { ve mesleki gelişimine yönelik } \\
\text { çalışmalara katılır. }\end{array}$ \\
\hline
\end{tabular}

Kaynak: Öğretmenlik mesleği genel yeterlilikleri. MEB Öğretmen Yetiştirme ve Geliştirme Müdürlüğü, Millı̂ Eğitim Bakanlığı, Ankara, 2017.

\section{Eğitimde Yapılan Mesleki Hatalar}

Öğretmenlerin yeterli mesleki yeterlik ve pedagojik donanımla görevlerine başlamamaları veya mesleklerini gerçekleştirirken mesleki gelişim ve öğrenmeye yeterince zaman ayırmamaları çeşitli mesleki hataların oluşmasına yol açabilmektedir. Öğretmen yetkinliği, alan yazında ögretmenlerin belirli bir bağlam içerisinde ögretme görevini başarılı bir şekilde yerine getirebilmek ve öğrenci davranışlarını değiştirebilmek için gerekli davranışları gösterebilme konusundaki inanışları olarak tanımlanmaktadır (Tschannen Moran, Woolfolk ve Hoy, 1998; Akt. Atıcı, 2001). Bu yetkinlik düzeyine özellikle mesleğin ilk yıllarında henüz erişememiş öğretmenlerin çeşitli mesleki hatalar sergilemeleri yüksek bir ihtimaldir. Yapılan mesleki hatalara bağlı olarak da çeşitli kalıcı veya geçici olumsuz etkilerin ortaya çıkması da kaçınılmaz bir durumdur.

Öğretmenlerin yaptıkları hatalar kişiden kişiye, okuldan okula, toplumdan topluma farkl11ık gösterebilmektedir. Yapılan hataların kimisi öğrenciye yönelik olduğu gibi kimisi meslektaşlara, 
yöneticilere, velilere ve başka paydaşlara yönelik de olabilmektedir. Alan yazında yapılan çeşitli araştırmalar öğretmen hatalarının oldukça geniş bir yelpazede olabileceğini göstermektedir (Özer, Gelen, Alkan, Çınar ve Duran, 2016). Yapılan önemli bazı öğretmen hataları arasında uygun olmayan disiplin yöntemleri, saldırgan tutumlar, öğrenciye mobbing yapma, yalnızlaştırma, alay etme, kayırmacılık yapma sayılabilir. Ayrıca çeşitli istismar davranışları yapma, seviyesi uygun olmayan öğrenci-öğretmen ilişkisi kurma, aşağılama, adil olmama, uygun öğretim metotları kullanmama, adil olmayan ölçme ve değerlendirme kullanma gibi durumlar da öğretmenlerden kaynaklı mesleki hatalar arasındadır. Bunların yanında, duyarsızlık, alanında yetkin olmama, zayıf liderlik ve yönetim becerileri, etik olmaya davranışlar gösterme, uygun olmayan tepkilerde bulunma, aslı olmayan suçlamalarda bulunma gibi davranışlar da eklenebilir (Orange, 2007). Sayılan bu hataların çeşitli nedenleri de bulunmaktadır. Bu nedenler arasında öğretmenin pedagojik yeterlik düzeyinin düşüklüğü, liderlik ve yönetim becerilerinin zayıflığı, etkili iletişim dilini kullanmama, mesleği sevmeme, tecrübesizlik, çeşitli önyargılar, iş yükü fazlalığı, stres, öğretmenin kişilik özellikleri, okul yönetiminden, çevreden ve ailelerden kaynaklı tetikleyici unsurlar vb. sayılabilir (Shallenberger, 2015; Yariv, 2011). Meslek hataları öğretmenlerin mesleki hayatlarının çeşitli evrelerinde çeşitli biçimlerde görülebilir. Ancak meslek hayatında yapılan bu hataların yeniden tekrarlanmaması veya bir hatanın farklı hatalara daha yol açmaması için yapılan hatalardan mesleki anlamda bir öğrenmenin ögretmenlere mesleki bir kazanım sağlayacağı düşünülmektedir.

\section{Hatalardan Öğrenme}

Hatalar, verili normların dışında yapılan sapma davranışları olarak tanımlanabilmektedir (Oser ve Spychiger, 2005). Normlar belirli toplumsal ve kurumsal işleyişin sağlanmasında ortaya konulan ve kabul edilen, kültürden kültüre değiş̧iklik gösterebilecek yapıdadır. Norm dışı davranışlar ise yanılma, hata veya sapma davranışı olarak ele alınmakla birlikte alan yazında negatif bilgi teorisi çerçevesinde de irdelenmektedir. Negatif Bilgi Teorisi toplum hayatında çoğunlukla zararlı, kaçınılması gereken veya avantaj1 bulunmayan bilgi olarak kabul edilen eylemlerden hareketle profesyonel öğrenme edinimine odaklanmaktadır (Gartmeier, Bauer ve Regensburg, 2008). Ayrica, negatif bilgi bireyin karar verme sürecinde hangi durumun doğru hangisinin yanlış ve nelerden uzak durulması gerektiği noktasında genellikle deneme-yanılma yoluyla ve informal yollarla edinilen bilgidir (Akpınar ve Akdoğan, 2010). Negatif bilgi, doğru ve yanlış eylemlerin sınırını belirlemek ve bunun farkında olmak, hedefe gitmeyen rotaları bilmek adına gerekli görülmektedir. Ancak bireyler her zaman yaptıkları hataların etkileri üzerinde düşünmeyebilirler veya buradan bir öğrenme edimi yoluna gitmeyebilirler (Gartmeier, Bauer, Gruber ve Heid, 2008; Rach, Ufer ve Heinze, 2013).

Lambe (2006), negatif bilgiyi dört temel boyuttan ele almıştır (Akt. Akpınar ve Akdoğan, 2010). Bunlar a) Kişinin neyi bilmediğini bilmesi (yetkinliğin farkındalık), b) Kişinin ne yapılmayacağını bilmesi c) Başarısızlıklar ve hatalar (hatalardan öğrenme) d) Bilgiyi çerçeveleme. $\mathrm{Bu}$ bağlamda ele alındığında negatif bilginin öğrenme-öğretme süreçlerinde oldukça yararı görülmekte ve "eğitici hatalar" bu sürecin önemli bir parçası olmaktadır. Kişisel özelliklerden, sosyal çevreden, çalışılan kurumdan vb. kaynaklı meslek hatalarının meydana gelmesi her ne kadar kaçınılmaz olsa da alan yazında bu hatalardan mesleki gelişim ve öğrenme sağlandığına ilişkin pek çok çalışmaya rastlamak mümkündür (McGregor, 2006; Schoemaker, 2011; Ulssperger, 2008). Yapılan mesleki hataların bireylerin kendilerine özeleştiri yapmasına, kendi eylemleri hakkında yansıtıcı düşünme geliştirmelerinde, kendilerini yenilemede, empati becerilerini güçlendirmede katkısı olabilmektedir (Shallenberger, 2015).

Her mesleğin kendi içinde çeşitli zorluk düzeyi bulunmakla beraber öğretmenlik mesleğinin en zor taraflarından birisi birbirinden farklı mizaca, aile yapısına, toplumsal kökene, karakter ve kişiliğe, farklı gelişim özelliklerine sahip onlarca öğrenciyi yönetebilmektir. Bu süreç içerisinde hem öğretmenden hem çalışılan bölgeden hem de öğrenciden ve okul ikliminden kaynaklı durumlar zaman zaman çeşitli hataların yapılmasına zemin hazırlayabilmektedir. Alan yazındaki çalışmalarda genellikle yapılan hataların ne olduğuna değinilmiş ancak hangi durumlarda ve nasıl gerçekleştiğine dair ayrıntılı bir betimlemeye rastlanmamıştır. Bu çalışmanın temel amacı öğretmenlerin meslek 
hayatları içerisinde daha çok hangi türde hataları hangi koşullar altında gerçekleştiğini ve bu hatalardan ne gibi bir mesleki kazanım elde ettiklerini ortaya koyabilmektir.

\section{Yöntem}

$\mathrm{Bu}$ çalışma nitel araştırma yöntemlerinden bütüncül tekli durum çalışması desenine göre tasarlanmıştır. $\mathrm{Bu}$ desende bir duruma ilişkin etkenler (ortamlar, bireyler, olaylar, süreçler vb.) bütüncül bir yaklaşımla derinlemesine araştırılmakta ve bu etkenlerin belirlenen durumu nasıl etkilediğinin üzerine odaklanılmaktadır. Bütüncül tekli durum deseni daha önceden ortaya konan çeşitli teorilerin test edilmesi, doğrulanması ya da çürütülmesinde kullanılan desen türleri arasında yer almaktadır. Bunun yanında genel standartlara uymayan, aşırı, aykırı ya da kendine özgü durumların çalışılmasında da bütüncül tekli durum deseni tercih edilmektedir (Yıldırım ve Şimşek, 2013). Ayrıca durum çalışmalarının diğer önemli bir özelliği ise okuyanı durumun içine ve deneyime götürmesidir (Patton, 2014). Öğretmenlerin meslek hayatlarında yaptıkları farklı hatalar mesleki bir durum olarak ele alınmış ve bu araştırma desenine uygun olduğu düşünüldüğünden bütüncül tekli durum çalışması desenini tercih edilmiştir.

\section{Çalışma Grubu}

$\mathrm{Bu}$ çalışmanın odağını mesleki hatalar ve deneyimler oluşturduğu için öğretmenlik mesleğini belirli bir süredir yapan kişilerden veriler toplanmıştır. Verilerin toplanmasında belirli (en az üç yıl) mesleki tecrübesi bulunan ve araştırmaya gönüllü olan, unutamadığı ve kendisinde iz bırakan hatası ya da hataları olmuş öğretmenlere ulaşılmak istenmiştir. Çeşitli branş ve kıdeme sahip, farklı okul türlerinde ve şehirlerde çalışan toplamda 38 öğretmenden araştırma verileri elde edilmiştir. Çalışma grubu belirlenirken maksimum çeşitliliğe (branş, kıdem, kademe, cinsiyet yönünden) önem verilmiştir. Çalışma grubuna ilişkin bazı demografik veriler Tablo 2'de verilmiştir.

Tablo 2

Çalışma Grubuna İlişkin Çeşitli Demografik Bilgiler

\begin{tabular}{|c|c|c|c|c|c|c|c|}
\hline Kod & Cinsiyet & Branş & Yaş & Kidem & Çalıştığ1 okul sayısı & $\overline{\mathrm{Il}}$ & Okul kademesi \\
\hline Ö1 & Erkek & Sosyal B. & 46 & 24 y1l & 10 & Ankara & Ortaokul \\
\hline Ö2 & Erkek & Elektrik & 46 & 22 y1l & 1 & İstanbul & Meslek Lisesi \\
\hline Ö3 & Erkek & Sınıf Öğr. & 47 & $21 \mathrm{y} 11$ & 7 & İstanbul & İlkokul \\
\hline Ö4 & Kadın & İngilizce & 33 & $10 \mathrm{y} 11$ & 5 & Ankara & Ortaokul \\
\hline Ö5 & Erkek & Türkçe & 36 & 13 y1l & 4 & İstanbul & Ortaokul \\
\hline Ö6 & Kadın & Sınıf Öğr. & 30 & $10 \mathrm{y} 11$ & 6 & İstanbul & İlkokul \\
\hline Ö7 & Kadın & Sınıf Öğr. & 29 & 6 y1l & 3 & İstanbul & İlkokul \\
\hline Ö8 & Kadın & Matematik & 26 & 4 y1l & 2 & İstanbul & Ortaokul \\
\hline Ö9 & Erkek & Fen B. & 31 & $10 \mathrm{y} 11$ & 3 & İstanbul & Ortaokul \\
\hline Ö10 & Erkek & Din K. & 49 & 23 y1l & 7 & İstanbul & Ortaokul \\
\hline Ö11 & Kadın & Sınıf Öğr. & 32 & 9 y1l & 3 & İstanbul & İlkokul \\
\hline Ö12 & Erkek & Elektrik & 45 & $20 \mathrm{y} 11$ & 2 & İstanbul & Meslek Lisesi \\
\hline Ö13 & Kadın & Okul Önc. & 47 & 17 y1l & 6 & Ankara & Okul Öncesi \\
\hline Ö14 & Kadın & Edebiyat & 49 & 24 y1l & 7 & Ankara & Anadolu Lisesi \\
\hline Ö15 & Kadın & Rehberlik & 51 & $25 \mathrm{y} 11$ & 3 & Ankara & Ortaokul \\
\hline Ö16 & Kadın & Edebiyat & 44 & $22 \mathrm{y} 11$ & 9 & Düzce & Anadolu Lisesi \\
\hline Ö17 & Kadın & Okul Önc. & 30 & 8 y1l & 3 & Düzce & Okul Öncesi \\
\hline Ö18 & Kadın & Matematik & 37 & 17 y1l & 4 & Ankara & Ortaokul \\
\hline Ö19 & Erkek & Türkçe & 39 & 17 y1l & 7 & Ankara & Ortaokul \\
\hline Ö20 & Erkek & Sinıf Öğr. & 33 & 9 y1l & 5 & İstanbul & İlkokul \\
\hline Ö21 & Kadın & Fen B. & 45 & $20 \mathrm{y} 11$ & 7 & Ankara & İmam H. Lisesi \\
\hline Ö22 & Kadın & Matematik & 35 & 13 y1l & 4 & Ankara & Ortaokul \\
\hline Ö23 & Kadın & İngilizce & 36 & 14 y1l & 3 & Düzce & Meslek Lisesi \\
\hline Ö24 & Kadın & Biyoloji & 42 & 18 y1l & 4 & Düzce & Anadolu Lisesi \\
\hline Ö25 & Kadın & Giyim Tek. & 49 & 28 y1l & 3 & Düzce & Meslek Lisesi \\
\hline Ö26* & Erkek & Tarih & 44 & 22 y1l & 4 & Düzce & Meslek Lisesi \\
\hline Ö27 & Kadın & Felsefe & 37 & $10 \mathrm{y} 11$ & 9 & Düzce & Meslek Lisesi \\
\hline
\end{tabular}




\begin{tabular}{cccccccc}
\hline Ö28 & Kadın & Beden Eğ. & 39 & 15 y1l & 3 & Düzce & Anadolu Lisesi \\
Ö29 & Erkek & Teknoloji & 38 & 14 y1l & 5 & Düzce & Özel Eğitim \\
Ö30 & Erkek & Din K. & 63 & 36 y1l & 10 & Düzce & Özel Eğitim \\
Ö31 & Erkek & Teknoloji & 35 & 13 y1l & 2 & Düzce & Özel Eğitim \\
Ö32 & Erkek & Elektrik & 54 & 31 y1l & 4 & Düzce & Meslek Lisesi \\
Ö33 & Erkek & Sinıf Öğr. & 61 & 40 y1l & 5 & Düzce & İlkokul \\
Ö34 & Erkek & Biyoloji & 48 & 24 y1l & 4 & Düzce & Fen Lisesi \\
Ö35 & Kadın & Matematik & 40 & 18 y1l & 3 & Düzce & Anadolu Lisesi \\
Ö36 & Kadın & Fizik & 40 & 20 y1l & 5 & Düzce & Anadolu Lisesi \\
Ö37 & Kadın & Okul Önc. & 42 & 19 y1l & 5 & Düzce & Okul Öncesi \\
Ö38 & Kadın & Almanca & 31 & 8 y1l & 3 & Düzce & Anadolu Lisesi \\
\hline
\end{tabular}

Tablo incelendiğinde katılımcı öğretmenlerin 16'sının erkek, 22'sinin kadın olduğu görülmektedir. Katılımcı gruptaki öğretmenlere branşları açısından bakıldığında 6 sınıf öğretmeni, 1 fizik öğretmeni, 1 tarih öğretmeni, 4 matematik öğretmeni, 2 biyoloji öğretmeni, 1 Almanca öğretmeni, 2 İngilizce öğretmeni, 2 Din Kültürü öğretmeni, 2 Fen Bilimleri öğretmeni, 2 Türkçe öğretmeni bulunmaktadır. Ayrıca, 1 Sosyal Bilgiler öğretmeni, 3 elektrik öğretmeni, 2 teknolojitasarım öğretmeni, 1 Beden Eğitimi öğretmeni, 1 felsefe öğretmeni, 1 Giyim Teknolojileri öğretmeni, 3 okul öncesi öğretmeni, 2 edebiyat öğretmeni ve 1 rehberlik öğretmeninin çalışma grubunda yer aldığı görülmektedir. Katılımcı öğretmenlerin yaş aralığının 26-63 arasında değiştiği görülmektedir. Kıdem yönünden bakıldığında en az kıdeme sahip öğretmenin 4 yıl, en fazla kıdeme sahip öğretmenin ise 40 yıl kıdeminin olduğu anlaşılmaktadır. Çalışılan okul sayısına göre bakıldığında öğretmenlerin 1 ile 10 farklı okulda şimdiye kadar görev yaptıkları görülmektedir. Görev yapılan ile bakıldığında ise 9 öğretmenin Ankara'da, 18 öğretmenin Düzce'de ve 11 öğretmenin ise İstanbul'da görev yaptığ1 anlaşılmaktadır. Çalışılan okul kademesi türünde ise 6 öğretmenin ilkokullarda, 10 öğretmenin ortaokullarda, 7 öğretmenin Anadolu Liselerinde, 7 öğretmenin meslek liselerinde, 3 öğretmenin engellilere yönelik eğitim veren özel eğitim veren meslek liselerinde, 1 öğretmenin fen lisesinde, 1 öğretmenin imam hatip lisesinde, 3 öğretmenin ise okul öncesi kurumlarda çalıştığ görülmektedir. Örneklem içinde yanında (*) işareti bulunanlar aynı zamanda okul yöneticisidir.

\section{Veri Toplama Aracı}

Araştırmanın verileri, araştırmacı tarafından hazırlanan form aracılığ ile elde edilmiştir. Form oluşturulmadan önce alan yazında öğretmenlerin meslek hataları ile ilgili çeşitli araştırmalar okunmuş ve bazı anahtar kavramlar (tecrübe, yetkinlik, pedagojiye hâkimiyet vb.) belirlenmiştir. Bu anahtar kavramlar etrafında öncelikle 3 soruluk bir görüşme formu tasarlanmış ve branşları birbirinden farklı beş öğretmenden pilot veriler elde edilmiştir. Elde edilen cevaplar doğrultusunda soru formu tekrar düzenlenmiş ve tek bir ana soruya bağlı alt sorular şeklinde oluşturulmuştur. Formun en son hali öncelikle alan uzman olan iki ögretim üyesine ve bir dil bilimciye inceletilmiş, bazı düzeltmelere bu görüşler sonunda yer verilmiş ve son haline böylelikle karar verilmiştir. Formda katılımc1 öğretmenlere şu soru(lar) yöneltilmiştir:

1. Meslek hayatınızda yaptığınız ve unutamadığınız hata ya da hatalar nelerdir? Bu hatayı ya da hataları yaptığınız zamanı düşünerek olayın öncesini, olay anını ve sonrasını detaylıca betimleyiniz. (Bu ana soruyu şu alt sorular etrafında düşünerek cevaplayınız.)

Alt sorular: Hatayı-hataları yaptığınızda nasıl bir okuldaydınız? Çalışma şartları nasıldı? Okulun bulunduğu konum, çevresi ve velileri ne durumdaydı? Kaç yıllık öğretmendiniz? Hatayı kime karşı yaptınız? Bu hata ya da hatalardan siz ya da başkası maddi-manevi zarar gördü mü? Bu hata ya da hatalardan neler öğrendiniz? Meslek hayatınıza ve mesleki gelişiminize ne gibi katkı sundu? Sizi olumlu-olumsuz dönüştürdü mü? 


\section{Verilerin Toplanması ve Analizi}

Veriler Eylül-Kasım 2019 döneminde toplanmıştır. Verilerin çözümlenmesinde içerik analizi tekniği tercih edilmiştir. İçerik analizinde temel amaç toplanan verileri açıklayacak çeşitli kavramlara erişmektir (Yıldırım ve Şimşek, 2013). Ortaya çıkan bulgulara bağlı olarak çeşitli ana temalar, alt kategoriler ve kodlar oluşturulmuş ve bunları destekler nitelikte doğrudan doğruya katılımcı görüşlerinden alıntılara da yer verilmiştir.

\section{Geçerlik ve Güvenirlik}

Araştırmanın geçerlik ve güvenirliğini test etmede öncelikle katılımcı teyidi esas alınmıştır. Katılımcı teyidi, verilen derlendiği kişilere erişilerek ortaya çıkan bulgular hakkında geri bildirim istenmesine dayanmaktadır. Araştırmacının ortaya çıkan bulgular etrafında yaptı̆̆ 1 yorumların katılımcının söylemek istedikleri ile örtüşüp örtüşmediği bu aşamada kontrol edilerek araştırmanın geçerlik düzeyi yükseltilir (Merriam, 2013). Geçerliliği ve güvenirliği artırmada kullanılan farklı bir yöntem ise uzman görüşüne başvurmaktır. Çalışmanın verilerine dayalı olarak ortaya çıkan tema, alt tema ve kodlar ilgili alanda uzman 3 akademisyene inceletilmiş ve onların da aynı ifadelere aynı kodları verip vermeyeceği ve oradan da hareketle alt-tema ve temalara ulaşıp ulaşmayacağ 1 kontrol edilmiştir. Eğitim bilimleri alanındaki 3 uzmanın geri bildirimleri ile Miles ve Huberman (1994) görüş birliği ve görüş ayrılığı katsayılarına göre güvenirliği 0,88 olarak hesaplanmıştır.

\section{Çalışmanın Etik İzni}

Yapılan bu çalışmada "Yükseköğretim Kurumları Bilimsel Araştırma ve Yayın Etiği Yönergesi" kapsamında uyulması belirtilen tüm kurallara uyulmuştur. Etik kurul izin bilgileri aşağıda sunulmuştur:

Etik Değerlendirmeyi Yapan Kurulun Adı: Düzce Üniversitesi Bilimsel Araştırma ve Yayın Etik Kurulu

Etik Değerlendirmenin Tarihi: 13.03 .2020

Etik Değerlendirmenin Sayısı: 2020-52

\section{Bulgular}

Araştırmada ortaya çıkan bulgulara ilişkin tema, alt temalar ve kodlar Tablo 3'te sunulmuştur.

Tablo 3

Öğretmenlerin Öğrencilere Karşı Yaptı̆̆ Hatalar

\begin{tabular}{|c|c|c|c|}
\hline Temalar & Alt Temalar & Kodlar & $f$ \\
\hline \multirow{4}{*}{ 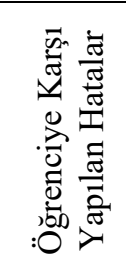 } & Kontrolsüz Öfkeli Davranış & Bağırma, hakaret etme, tehdit etme & 22 \\
\hline & Rencide etme & $\begin{array}{l}\text { Eksik yönlerini teşhir etme, küçük düşürme, hassas } \\
\text { ailevi durumları bilmeme }\end{array}$ & 12 \\
\hline & Şiddet uygulama & Tokat atma, dövme & 6 \\
\hline & Yanlış öğretim metotları & $\begin{array}{c}\text { Aşırı ödev verme, olması gerekenden fazla görev } \\
\text { yükleme, pedagojik bilgi eksikliği }\end{array}$ & 2 \\
\hline
\end{tabular}

\section{Öğrencilere Karşı Yapılan Hatalar ve Etkileri}

Öğretmenler tarafından yapılan mesleki hataların büyük bir kısmının etkileneni öğrenciler olmaktadır. Anlatılardan anlaşıldığı kadarıyla yapılan hataların çoğunluğu öğretmenlerin meslek hayatlarının ilk yıllarına denk gelmektedir. Farklı bir anlatımla mesleki deneyimin az olduğu meslek yıllarında öğrencilere yönelik yapılan hatalar çoğunlukta olmakla birlikte bu hataların etki büyüklüğü de o nispette fazla olmaktadır. Söz konusu hedef kitle küçük yaş grupları olduğunda ise hataların etkisi daha farklı olabilmektedir. Ayrıca, öğretmene oldukça değer verilen ve öğretmenden her şeyin beklendiği bir çalışma ortamında hatalardan öğrenme maliyeti ve bu hataların neden olduğu olaylar 
dizini de farklı olmaktadır. Söz gelimi aşağıda yer verilen örnek olayda bu duruma oldukça uygun düşmektedir:

“Ağrı merkezde görev yaptığım dönemdi. Okulun son günleriydi. Ortaokul öğrencileri (6. Sınıf) kendi aralarında bir otobüs tutarak geziye gitmek istiyorlardı. Bir sabah beni de oyuna getirerek geziye katılmamı sağladılar. Bu geziye, yıl boyunca beni diğer öğretmenlerden daha çok seven bir kız öğrencim de katılmıştı. Okula 10-15 km uzaklıkta bir yere gitmiştik. Gezide bahsettiğim kız öğrenci ile diğer öğrencilerim arasında bir problem olmuştu. Benden sürekli ilgi bekliyordu. Kız öğrencimin yaşanan tartışmada haksız olduğunu düşündüğüm için herkesin ortasında ona çok kızdım. Dolayısıyla aşırı alınganlık gösterdi. Çok üzüldü, ağladı ve küstü. Gezi yerini terk etti. Koşarak kaçtı. Buğday tarlalarından onu yakalamaya çalıştık. O sinirle yakalayınca bir de tokat attım. Geziyi üzgün bitirdik ama öğrenciyi de ailesi pek okutmak istemiyordu. O günden sonra okula gelmediği haberini aldım. Okulu bıraktı dediler. Bu durum hala içimde bir yara olarak yer almaktadır. O tokadı atmamalıydım. O öğrencinin diğer arkadaşları yanında sevdiği bir öğretmenden tokat yemesi benim çok büyük bir hatamdı. Eğer öğrenci psikolojisini bilseydim bu olay yaşanmazdı." (Ö1)

$\mathrm{Bu}$ örnekte görüldüğü üzere öğretmenin yeterli pedagojik donanımdan yoksun olması, bulunduğu yerin sosyolojik gerçekliğinden, aile yapılarından yeterince haberdar olmayışı bu önemli hatayı yapmasına neden olmuş ve hatanın sonucu öğrenci açısından oldukça ağır olmuştur. Farklı bir öğretmenin aşağıdaki anlatısı ise benzer şekilde mesleki formasyonun yetersizliğinden, sınıf kontrolünü sağlayamamaktan ve sınıf içi etkileşim metotlarını bilmemekten kaynaklı görünmektedir:

“Afyon'un bir kasabasında bir ortaokulda görev yapıyordum. Görevdeki ilk yılımdı. Bu yüzden sınıflarımda disiplin sağlamada zorlanıyordum. Hatırladığım kadarıyla 6 . sınıflarda bir gün öğrencilerin aşırı davranışlarından dolayı çok sinirlendim. Kendimi çaresiz hissediyordum. Bir türlü disiplini sağlayamıyordum sınıfta. Sınıftan çıktım ve öğretmenler odasına gidip sinirden ağladım. Okul küçük bir okuldu ve bu yüzden ağladığımı gören Türkçe öğretmeni arkadaş kendine bir görev çıkardı ki sınıftan en yaramaz öğrencileri alıp yanıma getirdi. Onlara önümde hakaret etti, onları tehdit etti. Öğrenciler dersimde sessiz durmaya başladılar ama hatam şu oldu ki benden değil başkasından çekindikleri için bunu yapıyorlardı. Niçin bu olmuştu? Onların dikkatini çekemiyordum galiba. Öğrencilik yıllarımda sınıf yönetimiyle ilgili acaba yeterli donanımım oluşmamış mıydı?” (Ö4)

Ö4 kodlu öğretmenin ifadeleri hata yapmasına neden olarak yetersiz mesleki donanımı, sınıf içi etkinliklerde tekdüzeliği, öğrencilerin dikkatini çekecek etkinliklere yer vermemeyi işaret etmektedir. Ayrıca başka bir öğretmenin olaya müdahil olması ise kendi mesleki yetersizliğinin öğrenciler nezdinde yeniden pekiştirilmesi olarak da yorumlanabilir. Öğretmenleri hataya sevk eden farklı bir faktör ise öfke kontrolünün yeterince sağlanamaması ve buna bağlı olarak da ortaya çıkan şiddet içeren eylemlerdir. Öğretmenlerin öğrencilere karşı sert bir görüntü sunarak onları kontrol altına alma düşüncesi bazı hataların da meydana gelmesine neden olmaktadır. Ayrıca öğretmenlerin kendi öğrencilik yıllarında hatırlarında kalan öğretmen rol ve davranışlarının sosyal öğrenme yoluyla kendilerine de etki ettiği anlaşılmaktadır. Aşağıda yer verilen örnek olay bu durumu doğrular niteliktedir:

“Öğretmenliğimin ilk yıllarıydı. Henüz tecrübe edinmemiş bir öğretmenken kendi öğrencilik yıllarımızdaki öğretmenlerimizden gördügümüz davranış kalıplarının etkisiyle öğrencilerimi çok seviyor olmama rağmen şımarıklıkları için dayak attığım öğrencilerim oldu. Hatta dayağı abarttığım zamanlar da oldu. Oysaki ben öğrencilerim için okul idaresine tavır koyuyor, onlar için okul idaresiyle kavga bile ediyordum. Harçlı̆̆ biten öğrenci benden rahatlıkla harçlık bile isterdi. Tüm dertlerini benimle paylaşırlardı. Onlara dayak attığım için benden uzaklaşmadılar ancak attığım o dayaklardan dolayı kendimi kötü hissediyorum ve unutamıorum.” (Ö10) 
Yukarıdaki anlatıda öğretmenin kendi içinde rol çatışması yaşadığı da görülmektedir. Bir yandan koruyucu-kollayıcı bir öğretmen rolü sunarken diğer yandan ise öğrencilerine karşı şiddet içeren davranıșlar sergilemesi kendi içinde bir çelişki olarak görülebilir. Bu durum yine, deneyimsiz olmanın, öfke kontrolünü yapamamanın, fevri davranmanın ve öğrencilerin istenmeyen davranışlarını ortadan kaldırmak için en etkili çözüm olarak öğrenciye yönelik şiddeti ilk olarak ele almanın bir uzantısı olarak değerlendirilebilir. Öğretmenleri öğrencilerine karşı hataya sevk eden diğer önemli bir faktör ise önyargılar ve bir durum hakkında etraflı bilgi sahibi olmadan yapılan ezberlenmiş ani davranış kalıpları olmaktadır. Öğrencilerin içinde bulunduğu ailevî ve toplumsal gerçekliğin farkında olmadan, her birini homojen ve mekanik bir statüde ele aldıklarında öğretmenlerin çeşitli hatalar yapabildikleri görülmektedir. Benzer şekilde, rol-model öğrenmeyle edinilmiş öğretmen davranışlarına aşağıda sunulan olay da iyi bir örnek olarak verilebilir:

"1994 yılında 6 yıllık öğretmenken ikinci çalıştığım okulda müdür yardımcısı olarak göreve başladım. Görev yaptığım okul büyük bir meslek lisesiydi. İki bin beş yüz civarında öğrencimiz vardı. Okulun kalabalık olması ve gelen öğrencilerin okuma isteği olmayan öğrenciler olmasından dolayı disiplin olayları oldukça fazlaydı. Ben de idareciliği bağırmak, çağırmak, kızmak, affetmemek olarak biliyordum. Çünkü öyle görmüştüm, öyle yaptım. Öğrencilerimin haklı olabileceklerini düşünmeden sırf disiplin olsun diye kararlar veriyordum. Bir zaman geldi ki öğrenciler beni gördüğünde yolunu değiştirmeye, saklanmaya çalıştıklarını fark ettim. Öğrencilerimin benden korkudan yardım dahi isteyemediklerini fark ettim. Anladım ki derdini bilmediğim öğrencinin problemini çözemeyecektim. O gün idareciliğin böyle olmaması gerektiğini anladım. Öğrencileri dinlediğimde ne dramlar, ne öyküler olduğunu gördüm.” (Ö32)

Yukarıda söz edilen anlatı yine benzer şekilde yanlış modelleme ile edinilen davranış kalıplarının yansımaları olarak okunmalıdır. Okul yöneticilerini sert, otoriter, aşırı disiplinli insanlar şeklinde bilişsel şemasına kodlayan öğretmenin kendisinin de aynı role girmesi beraberinde çeşitli hataların da oluşmasına neden olmuştur. Ancak öğretmenin hatasını fark etmesi ve bu hatadan dönerek öğrencileri yeniden kazanma yolunda hareket etmesi ise mesleki kazanım ve öğrenme anlamında oldukça değerlidir. Öğretmenleri hata yapmaya zorlayan farklı bir etken ise çeşitli önyargılar olabilmektedir. Öğrencilerin ve ailelerinin içinde bulundukları durumdan haberdar olmadan aşırı ve önyargılı tepkiler geliştirmek beraberinde hataların da oluşmasına yol açabilmektedir. Aşağıdaki olay bu yönde bir örnek oluşturmaktadır:

"Hatayı kendi öğrencime önyargılı davranarak yaptım. Öğrenci ders çalışmıyor, defter kitap getirmiyordu. Öğrencimi sorumluluğunu bilmeyen, tembel biri olarak kodlamıştım. Bir defasında aşırı tepki gösterdim ve ailesini de aradım. Ancak öğrendim ki öğrencinin ailesi dağılmış ve maddi zorluklar içerisindeler. Evlerinde elektrik ve su dahi yok. Öğrencinin defter alacak parası yokmuş ve okul dışında ailesine bakmak için bir işte çalışıyormuş. Çok üzüldüm ve kendime kızdım. Ama öğrendim ki her şeyden önce öğrencilerimi ayrıntılı tanımalıyım." (Ö12)

Öğretmenlerin mesleğin ilk yıllarında yaptıkları hataların öğrencileri rencide edici tarafları bulunmaktadır. Deneyimsiz olmanın ve sonucu kestirememenin yol açtığı bu durum kimi zaman öğrencilerin hayatlarında uzun süreli olumsuz etkiler bırakabilmektedir. Öğrencilerin olumsuz örneklerini diğer akranları önünde pekiştirerek teşhir etmenin öğrencilerde oluşturacağı psikolojik ve pedagojik yıkım bu türden hataların uzantıları olarak gerçekleşebilmektedir. Söz gelimi, aşağıda sunulan olay bu duruma önemli bir örnek oluşturmaktadır:

“Kız Meslek Lisesine yeni atandığım dönemlerde öğrencilerimize etek dikimi yaptırıyorduk. Öğrencimin bir tanesine etek dikimi yaparken beline geçirdiği lastiğin uçlarını üst üste getirerek dikmesini belirtmiştim. Öğrenci dikmek yerine lastiği düğüm atarak kocaman bağlamıştı. Ben de öğrencimin yanlışını bütün sınıfta örnek olsun diye 
gösterip öyle bağlanmaması gerektiğini, bu şekilde babaannelerimizin yaptığını belirtip sınıfin önünde onu rencide ettim. Tabi ben bu olayı yıllar sonra unuttum. Aradan 4-5 y1l geçti. Sonra başka öğrencilerimle bir fabrikada işbaşı eğitim için bulunduğumuzda bu eski öğrencimle karşılaştım. Orada şef olarak çalışıyordu. Bana kendisini tanıtırken onu rencide ettiğim o günü hatırlattı. $\mathrm{O}$ an anladım ki örnek verirken öğrencilerimin onurunu ve gururunu kırmamam gerekiyor. Şimdi yılların verdiği tecrübe ile daha dikkatli davranıyorum." (Ö25)

Başka bir örnek olayda ise öğrencilerin özel durumlarından ve hassasiyetlerinden haberdar olmamaktan kaynaklı öğretmen hatalarının olduğu görülmektedir. Bu anlatı aynı zamanda öğrencilerin ailelerini ve yaşam şartlarını yakından tanımanın ne kadar önemli olduğunu da göstermektedir:

"Mesleğimde beşinci yılımdı. Bir ortaokulda çalışıyordum. Merkeze bağlı bir kenar mahalle okuluydu. Veliler genellikle okula uğramaz, toplantılara katılmaz, çocuklarıyla pek ilgilenmezlerdi. Bundan dolayı kendimin rehber öğretmeni olduğu sınıfın dışındaki çocukların velilerini pek tanımıyordum. Hangisi ölmüş hangisi yaşıyor pek fikrim yoktu. İşte tam da bu nedenle bu hatayı yaptım. Beşinci sınıf öğrencilerime aile konusu işledikten sonra aile bireylerini tanıtma ödevi vermiştim. Ertesi gün derste ödevlerini sunuyorlardı ki bir öğrenci derse çok ilgisizdi. Ödevini yapmıştı ama okumak istemiyordu. Okuması için zorladım onu. Annesini, diğer büyüklerini ve kardeşlerini tanıttı. Ama babasını tanıtmadı. Tekrar sorduğumda gözlerinden ateş fişkırıyordu. Koşarak sınıftan çıktı. Diğer öğrencilere sorduğumda babasının olmadığını öğrendim ve başımdan kaynar sular dökülmüştü. Yıllar önce babasını kaybetmiş ve bu konuda çok hassasmış. O öğrencimle o gün daha hiç konuşamadım. Başka bir gün konuştum. Babasını çok özlediğini dile getirdi bana. O öğrencim sayesinde öğrencilerin aile durumlarını bilmenin ne kadar önemli olduğunu öğrendim. Öğretmen olarak başarılı olmanın öğrenciyi her yönüyle tanımaktan geçtiğini idrak ettim. Bu olaydan sonra sınav sorularında dahi anne-babalarla ilgili sorular sormuyorum.” (Ö23)

Yukarıdaki örnekte olduğu gibi öğrencilerin psikolojik yıkım yaşayacağı, acılarını tazeleyeceği durumların ortaya çıkmaması için öğretmenlerin bu gibi hassas durumların farkında olması oldukça önemli görünmektedir.

\section{Öğretmenlerin Hata Yapmasına Neden Olan Faktörler}

Öğretmenlerin yaşadıkları örnek olaylardan ve yapılan hatalardan hareketle bu hataların yapılmasına yol açan temel faktörler sekiz başlık etrafında toplanmaktadır. Bu faktörler Tablo 4 'te sunulmuştur.

Tablo 4

Öğretmenlerin Mesleki Hata Yapmalarına Neden Olan Faktörler

\begin{tabular}{cc}
\hline Faktörler & $f$ \\
\hline Pedagojik yetersizlik & 18 \\
Tecrübesizlik & 17 \\
Aileyi, öğrenciyi ve çevreyi yeterince tanımama & 10 \\
Öğrencinin gelişim özelliklerini yeterince bilmeme & 10 \\
Önyargıllar & 8 \\
Öfkeyi kontrol edememe & 7 \\
İşyükü fazlalığı & 4 \\
Stres & 3 \\
\hline
\end{tabular}

Yukarıda sayılan faktörlere ve anlatılan örnek olayların yaşandığı dönemlere bakıldığı zaman öğretmenlerin meslek hayatlarının ilk yıllarındaki pedagojik yetersizliklerinin ve tecrübesizliklerinin onları önemli ölçüde hata yapmaya sevk ettiği anlaşılmaktadır. Örnek olaylarda pedagojik yetersizliğin iki farklı durumu söz konusu olmaktadır. Birincisi öğretmenlerin eğitim fakültelerinden yetersiz 
donanımla mezun olmaları iken ikincisi ise öğrencinin psiko-sosyal gelişim özelliklerini yeterince bilmemelerinden kaynaklı görünmektedir. Söz gelimi Ö1 kodlu öğretmenin "Öğrencilerin davranış psikolojilerini yeterince bilmediğim için ve formasyonun gerektirdiği davranışı yapmamadan dolayı ögretmenliğin ilk yıllarında beni hala etkileyen hatayı yaptım." sözleri bu duruma önemli bir örnek oluşturmaktadır. Ö10 kodlu öğretmenin söylediği "Kendi ögrencilik ylllarımızda öğretmenlerimizden gördüğ̈̈müz davranış kalıplarının etkisiyle öğrencilerimi çok sevmiş olmama rağmen şımarıklıkları için dayak attığım öğrencilerim oldu" ifadeleri henüz olgunluğa erişmemiş pedagojik bilginin eksikliği ile çeşitli hataların işlendiğini göstermektedir. Ö5 kodlu öğretmenin "Üniversiteden yeni mezun birisi olarak kendimi köy okulunda yapayalnız hissediyordum. Her ne kadar fakültede bir şey görmüss olsak da gerçek hayatta kazın ayağının öyle olmadı̆̆ını anladım. Son sınıfta gittiğimiz stajda da rehber ögretmenlerin bize fayda sağlamadığını gördüm” ifadeleri yetersiz pedagojik donanımın öğretmenlerde çeşitli durumlar karşısında uygun davranış geliştirememelerini anlatması bakımından önemlidir. Ö9 kodlu öğretmenin "Geçmişte sınıf yönetimi için öğrencilere sert davranmak gerektiğini, çok yüz vermemek gerektiğini düşünüyordum. Bu yüzden sinıfimda çok gülmüyor, sevgimi, insani yönlerimi göstermemeye çalışıyordum" sözleri de geleneksel davranış kalıplarının sürdürülmesi, eski pedagojik anlayışın devam ettirilmesi şeklinde değerlendirilebilir.

Tecrübesizlik ise diğer bir önemli hata kaynăg 1 olarak öğretmenler tarafindan vurgulanmaktadır. Özellikle sınıf yönetimi ve kontrolü sağlama konusunda mesleğin ilk yıllarında yaşanan sorunlar ve buna bağlı olarak ortaya çıkan mesleki hatalar büyük ölçüde mesleki tecrübe eksikliğinden kaynaklı görünmektedir. Söz gelimi Ö4 kodlu öğretmenin “Afyon'un bir kasabasinda yine bir ortaokulda görev yaplyordum. Görevdeki ilk yllimdl. Bu yüzden sinıflarımda disiplini sağlamada zorlanıyordum." ifadeleri bu yönde değerlendirilebilir. Ö8'in "Tecrübesizlikten ya da öğretmenliğe başladı̆̆ım dönemlerde acemilikten çeşitli hatalarım olmuştur" sözleri de tecrübesizliğin hata olasılığını artırdığına ilişkin ipuçları sunmaktadır. Pedagojik yetersizlikle birlikte tecrübesizlik ele alındığında her ikisinin de mesleğin ilk yıllarında kesişiyor olması ve bazen de ikisinin anlatılan aynı örnek olaylarda bir arada bulunması telafisi zor sonuçları olan hataların yapılmasına da sebep olduğu görülmektedir.

Öğretmenleri hataya sevk eden diğer önemli bir faktör ise görev yaptıkları yerin toplumsal gerçekliğini, ailelerin ve çocukların varsa özel durumlarını bilmemek olarak görülmektedir. Bu durum özellikle aile büyüklerinden birini ya da birden fazlasını kaybetmiş öğrencilere aileleri ile ilgili öğretmenleri tarafından soru sorulduğunda ya da çeşitli ödevler verilip bunu sınıf içerisinde dile getirmeleri istendiğinde ortaya çıkmaktadır. Yaşanan travmaların bu tür durumlarla yeniden tazelenmesi öğrencilerin duygusal ve psikolojik olarak olumsuz etkilenmelerine yol açabilmektedir. $\mathrm{Bu}$ durum yine tecrübesizlik ve pedagojik yetersizlik ile iç içe geçmiş şekilde de ele alınabilir. $\mathrm{Bu}$ duruma örnek olarak Ö16 kodlu öğretmenin şu ifadeleri verilebilir:

"Mesleğimin ilk y1lıydı. Bir ilköğretim okulunda Türkçe öğretmeni olarak görev yapıyordum. Öğrencilerle tanışma esnasında adlarını, soyadlarını, anne-baba mesleklerini vb. sordum. Bir öğrencim bu esnada hıçkırıkla ağlamaya başladı. O kadar çok ağladı ki... $O$ gün kahrımdan kendi kendimi yedim. Meğer annesi vefat etmiş. $O$ günkü üzüntümü anlatamam. O günden sonra karar verdim bir daha hiçbir zaman anne-babayla ilgili sınıfta özel soru sormamaya. Toplum içinde bu tip soruların yıkımı çok oluyor.” (Ö16)

Benzer şekilde Ö23'ün üst paragraflarda yaşadığı örnek olay da bu kategori içinde ele alınmalıdır. Ö17 kodlu öğretmenin Ağrı'da görev yaparken yaptığı hata (üst paragraflarda geçtiği üzere öğrenciye tokat atma şeklindedir) ise öğrencinin eğitim hayatının bitmesine yol açmıştır. Kız çocuklarının okula gönderilmesine yönelik var olan ailevî ve toplumsal tabulardan haberdar olmadan yapılan hatanın bedeli ağır olmuştur. Bu duruma farklı bir örnek ise öğrencilerin ve ailelerinin içinde bulundukları çeşitli ekonomik sıkıntılardan haberdar olmadan öğrencilerden beklentileri yüksek tutmak ve beklentilerin karşılanmaması halinde ise ortaya çıkan hatalar ve istenmeyen durumlar sayılabilir. Örneğin Ö22 kodlu öğretmenin şu ifadeleri bu yöndedir: 
"Öğrencime yaptığım o hatayı unutamıyorum. Matematik branşının yükü var. Mesleğimin ikinci yılıydı. İstanbul'da çalışıyorum. Ödev konusundaki hassasiyetimi sürekli vurguluyorum. Bir öğrencim ödev yapmadan gelmiş. $O$ an öfkeleniyorum ve ağzıma ne gelirse sayıyorum. Mesleğimin ikinci yılıydı. İstanbul'da çalışıyorum. Ödev konusundaki hassasiyetimi sürekli vurguluyorum. Bir öğrencim ödev yapmadan gelmiş. $\mathrm{O}$ an öfkeleniyorum ve ağzıma ne gelirse sayıyorum. Oysaki öğrencimin maddi durumu çok yetersiz ve öğrencim okula çok zor şartlar altında geliyormuş. Arkasındaki nedeni araştırmadan o anlık duyduğum öfke ile bu hatayı yaptım.” (Ö22)

Farklı ve trajik bir örnek ise şu şekildedir:

"Mesleğimin ilk yılıydı. Zorunlu hizmet bölgesine çalışıyordum. Okulumun öğrencileri ve aileleri yoksuldu. İlk dönemin ikinci sınavı yaparken bir kız öğrencimin kopya çektiğini gördüm. Kendisinden sınav kâğıdını istediğimde hocam yazacaklarımı bitireyim, öyle vereyim dedi. Fakat ben hışımla kâğıdı önünden çektim. Kâğıt biraz yırtıldı. O kadar sinirlendim ki ona ben bu derse girdiğim sürece zor geçersin diyerek de tehdit ettim. Yani işi şahsileştirdim. Hakikatinde o öğrencimden dolayı tüm sınıfın sorularını zorlaştırmıştım. Ama bunu yapmamam gerekiyordu. Yaz tatilinde o öğrencimin böbrek yetmezliğinden vefat ettiğini öğrendiğimde dakikalarca üzüntümden ağladım. Pişmanlık duydum. Bu olaydan sonra hiçbir sorunu şahsileştirmemeye gayret ediyorum." (Ö26)

Öğretmenlerin hata yapmasına yol açan diğer farklı bir etken ise öğrencinin psiko-sosyal, bilişsel ve davranışsal gelişim seyrini tam bilememeleri ve buna bağlı olarak ortaya çıkan durumlar olarak görülmektedir. Bu etken esasında yine tecrübesizlik ve pedagojik bilgi eksikliği ile de iç içe geçmiş vaziyettedir. Örneğin, Ö24 kodlu öğretmenin söylediği aşağıdaki ifadeleri bu yönde değerlendirilmelidir:

"Meslek hayatımın ilk başladığı senelerde öğrencileri aşırı şekilde ders çalışmaya zorlamam ve destek olmak amacıyla aşırı ödev yüklemesi yapmış olmam ve öğrencinin yapabileceğinden çok sorumluluk vermem beni öğrencinin gözünde canavara dönüştürmüş diye düşünüyorum”. (Ö24)

Öğrencinin bilişsel kapasitesinin tam farkında olmadan, gelişim ve öğrenme çağının özelliklerini yeterince bilmeden ve verilen çalışmaları öğrencilerin yapabilecek materyal ve imkânlara sahip olup olmadığını tam olarak anlamadan yapılan girişimler beraberinde çeşitli sorunları ve hataları da getirmiştir. Bu konuda farklı ve oldukça önemli bir deneyim ise 40 ylllık mesleki tecrübesi olan bir sınıf öğretmeninin (Ö33) mesleğin ilk yıllarında yaşadığ durumla ilgilidir. Birleştirilmiş sınıflarda eğitim veren bir köy okulunda çalışırken ilkokul birinci sınıf öğrencileri ile yaptığı çalışmaları bulunduğu yerin ve çocukların özelliklerini tam bilmeden yürütmesi bazı hataların oluşmasına neden olmuştur. Ö33 kodlu bu öğretmenin söylediği "Bazen çok şey ögretebilme arzusu ve heyecanıyla hata yapılabileceğini yaşayarak öğrendim. ” sözleri durumun özeti niteliğindedir.

Önyargılar öğretmenlerin hata yapmasına yol açan diğer önemli bir faktör olarak ele alınabilir. Öğrenciye, ailesine ya da çevreye karşı geliştirilen çeşitli hazır kalıp düşünceler, önyargılar ya da öğrencinin bir olumlu-olumsuz özelliğinden yola çıkarak genele ilişkin kanaat elde etmeye yönelik eğilimler hataların yapılmasına neden olabilmektedir. Ö18 kodlu öğretmenin şu sözleri bu yönde değerlendirilebilir:

“6. Sınıfta matematik dersine girdiğimde bir kız öğrencimin ağladığını gördüm. Önce öğrenci kavgasıdır diye önemsemedim. Sonra yanına gittiğimde öğrencinin öne oturmak istediğini öğrendim. Daha önce yaşanan yer kavgası aklıma geldi ev bunlara sinirlenip herkes öne oturmak istiyor ben ne yapabilirim diye bu öğrenciyi rencide ettim. Bir gün sonra velisi geldi. Kızının gittikçe görme kaybı yaşadığını ve öne oturması gerektiğini ağlayarak dile getirince başımdan aşağı kaynar sular döküldü. Suçluluk duygusu ile 
anlamadan, dinlemeden hareket etmenin verdiği mahcuplukla annesi ve kızından özür dileyip hemen ön sıraya aldım. İnsanları ciddiyetle dinleyip en küçük şikâyeti bile önemsemem gerektiğini anladım. Öğretmenlik empati gerektiren, sabır isteyen bir iştir." (Ö18)

Benzer bir durum farklı bir öğretmenin şu ifadelerinde yer almaktadır:

"Hatayı kendi öğrencime önyargılı davranarak yaptım. Öğrenci ders çalışmıyor, defter kitap getirmiyordu. Öğrencimi sorumluluğunu bilmeyen, tembel biri olarak kodlamıştım. Bir defasında aşırı tepki gösterdim ve ailesini de aradım. Ancak öğrendim ki öğrencinin ailesi dağılmış ve maddi zorluklar içerisindeler. Evlerinde elektrik ve su dahi yok. Öğrencinin defter alacak parası yokmuş ve okul dışında ailesine bakmak için bir işte çalışıyormuş. Çok üzüldüm ve kendime kızdım. Ama öğrendim ki her şeyden önce öğrencilerimi ayrıntılı tanımalıyım.” (Ö12)

Öfke kontrolünü sağlayamama diğer bir hata faktörü olarak öğretmenler tarafindan belirtilen nedenler arasında yer almaktadır. Okulda ya da sınıfta yaşanan çeşitli istenmeyen durumların yönetilmesinde başarısız olmak ve öfkeye yenik düşmek beraberinde çeşitli hataların ortaya çıkmasına yola açabilmektedir. Örneğin Ö19 kodlu öğretmenin şu sözleri bu yönde ele alınabilir:

“2010 yılında Etimesgut’ta müdür yardımcıllı̆ı yaparken bir velinin tavırlarına karşı sinirlerime hâkim olamayıp ciddi bir tartışmaya giriştik. Veli ile öğrencilerin gözü önünde bağrıştık ve birbirimize hakaret ettik. Bu oldukça kötü bir durumdu. Bir öğretmen sinirlerine hâkim olabilmelidir ve bazı durumları soğukkanlılıkla yürütmelidir. Tartıştığım velinin de kabahati olmasına karşın kendimi o pozisyona sokmamalıydım. Bir öğretmen her zaman stratejik davranmalıdır." (Ö19)

Son olarak, öğretmenlerin hata yapmalarına neden olan iki faktör ise iş yükü fazlalı̆̆ 1 ve stres olarak belirtilmiştir. Özellikle belirli branşlarda belirli okullarda eğer öğretmen sayısı yetersiz ise ve var olan işler de mevcut öğretmenlere dağıtılmış ise iş yükünde bir artış söz konusu olmaktadır. $\mathrm{Bu}$ durum öğretmenlerde strese yol açmakta ve ortaya çıkan gerilim onların çeşitli hatalar yapmasına yol açabilmektedir. Söz gelimi, Ö17 kodlu öğretmenin şu anlatısı bu duruma örnek olabilir:

“Meslek hayatımın ikinci yılıydı. Ağrı'da bir ilkokulda çalışıyordum. Sabah ve öğlen olmak üzere iki sınıftık. Diğer öğretmen doğum iznine ayrılmıştı. Sene başıydı. Okul müdürü ücretli öğretmen almak yerine iki sınıfi birden bana vermişti. Daha meslekte çok toydum ve 55 tane öğrencim vardı. Sene başı olduğu için çocukların çoğu okulda problem çıkarıyordu. Bir ay sonra dayanamadım ve müdürüme sınıfı bölmemiz gerektiğini söyledim. Toplantı yaptık ve sınıfı böldük. Ancak yine bende 30 öğrenci vardı. Sınıf bölündükten sonra diğer sınıfın öğrencileri tekrar bana gelmeye başladı. Bu çocukların ailelerine sorduğumda müdürle konuştuk size gelecek cevabını alıyordum. Bu stresli durumun üzerine bir de müdürün gülerek nasıl gidiyor hoca hanım demesi üzerine gerildik ve tartışmaya başladık. Bana elli de desem yüz de desem alacaksın, beceremiyorum dersen çekip gideceksin dedi. Beni sindirdi. Bunun kendi açımdan büyük hata olduğunu düşünüyorum. Ancak şimdi olsa ilgili her yere başvururum.”(Ö17)

Yukarıdaki ifadeler hem öğretmenin mevzuat bilgisi yetersizliğinden hem de okul yönetiminin etkili bir sorun çözme becerisi sergilememesinden kaynaklı olarak hataların ortaya çıktığını göstermektedir. Ayrıca öğretmenin iş yükü fazlalığı psikolojik yıpranmayı da artırdığından istenmeyen olayların çıkması da hızlanmaktadır. Meslekte yeni olan öğretmene okul yöneticisinin etkili rehberlik ve liderlik etmesi yerine ona türlü mekanizmalar ile bask1 yapması ise öğretmenin ve okul yönetiminin karşılıklı hatalar yapmasını tetikleyen başka bir faktör olarak ele alınmalıdır.

Şimdiye kadar ele alınan örnek olaylardaki hatalar ve bu hataların oluşmasındaki faktörlerin özeti şekil 1'de sunulan görselde görülebilir. 


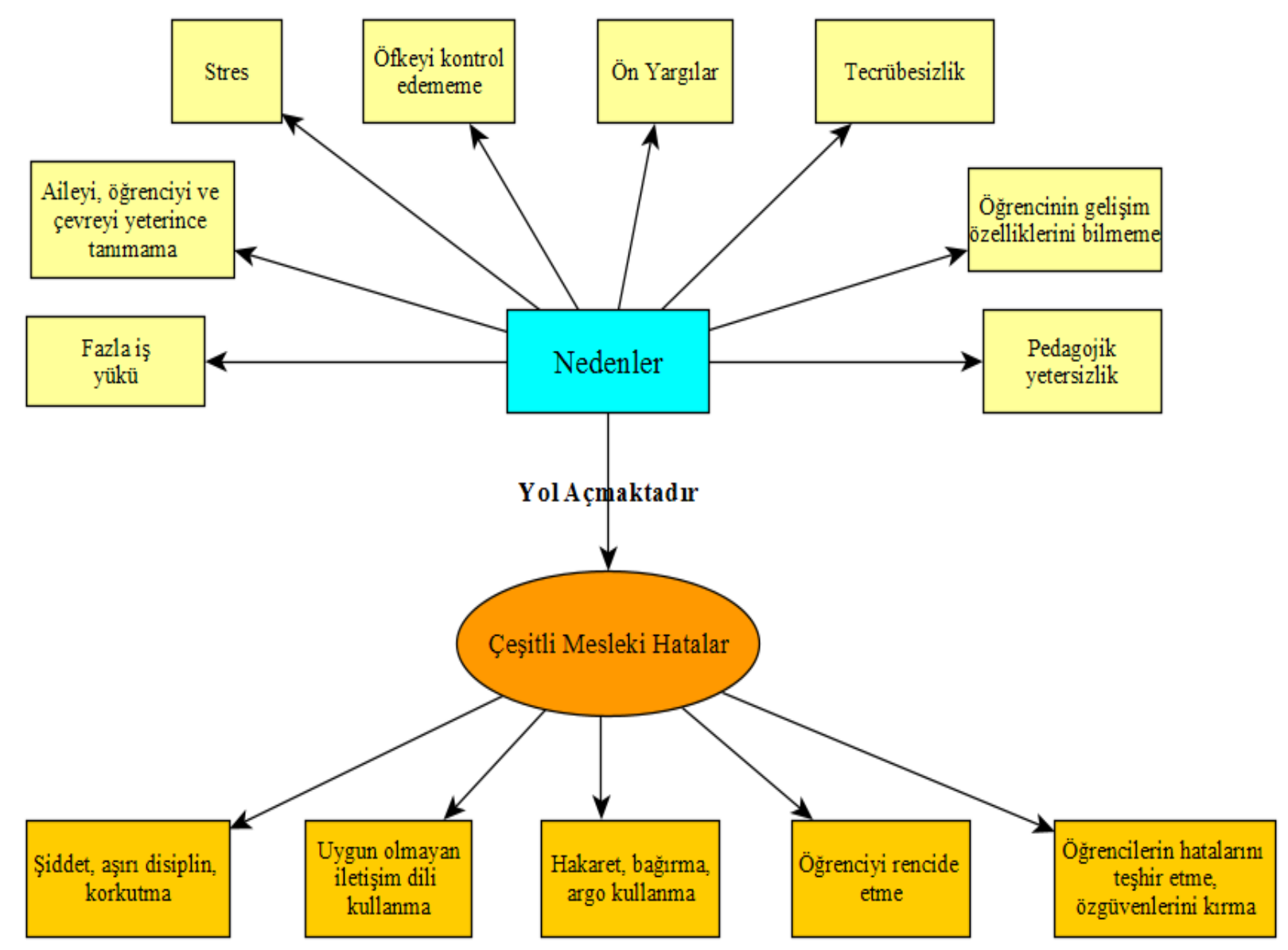

Şekil 1. Öğretmenlerin Yaptıkları Çeşitli Mesleki Hatalar ve Nedenleri

\section{Sonuç, Tartışma ve Öneriler}

$\mathrm{Bu}$ çalışma öğretmenlerin meslek hayatlarında yaptıkları farklı mesleki hataların çeşitli pedagojik etkilerini ortaya koymak ve bu hataları öğretmenlerin mesleki öğrenme ve kazanımları çerçevesinde ele almayı amaçlamaktadır. Öğretmenlerin başlarından geçen çeşitli örnek olaylar ve yapılan hatalar sadece yaşanmış ve geçmişte kalmış durumlar olarak ele alınmamalıdır. Bu örnek olay ve hataların nostaljik yönü olduğu kadar öğretici tarafları da bulunmaktadır. Farklı şehirlerde, farklı branş ve kıdemlerde görev yapan öğretmenlerin yaşadıkları birbirinden bağımsız olayların ve yaptıkları hataların onların mesleki öğrenmelerine katkı sağladığı ve mesleki olarak gelişimlerini desteklediği görülmektedir. Öğretmenlerin yaşadıkları çeşitli ortak olumsuz deneyimlerin ortaya çıkmasının gerisinde de benzer faktörlerin yer aldığı görülmektedir. Öğretmenleri hataya sevk eden en güçlü nedenler arasında pedagojik yetersizlik ve tecrübesizlik görülmektedir. Mesleki hataların büyük kısmı mesleğin ilk yıllarında ağırlıklı olarak da iletişim ve sınıf yönetimi üzerine yapılmaktadır (Duman, 2010; Kozikoğlu ve Senemoğlu, 2018). Özellikle kendisine rehberlik edecek bir deneyimli öğretmenin olmadığı durumlarda göreve yeni başlayan öğretmenlerin mesleki hata yapma olasılığı da artmakta ve bazı mesleki kazanımları deneme-yanılma yoluyla elde etmektedirler (Sarı ve Altun, 2015). Öğrencilere yönelik yapılan hataların büyük kısmında öğretmenlerin etkili iletişim becerilerini kullanamaması, istenmeyen durumların ve çatışmaların yönetimi konusunda etkili stratejilere başvurulmaması, öfkeyi kontrol edememe gibi nedenlerin öğretmenleri hata yapmaya sevk ettiği anlaşılmaktadır. Bu durum öğretmenlerin baskıcı ve otoriter tutum geliştirmesine yol açmakta ve o da öğrencide yüksek kayg1, korku, özgüven eksikliği, derse ve öğretmene karşı önyargı geliştirme gibi durumlara neden olabilmektedir (Sezer, 2018). Ancak olumsuz deneyim yaşayan öğretmenlerin hemen 
hemen tümünün yaptıkları çeşitli hataların kendileri için bir kazanım oluşturduğu ve mesleki olarak bir öğrenme edimi elde ettikleri de anlaşılmaktadır.

Tjosvold, Yu ve Hui (2004) hataların öğrenme üzerinde önemli bir paya sahip olduğunu belirtmektedir. Bunun yanında hatalardan çeşitli edinim ve kazanımlar elde etmekten kaçınan insanlar da bulunmaktadır. Bunun temel nedeni olarak hatanın utanç verici bir eylem olduğu fikri ve hatanın bireyde yetersizlik hissi oluşturması gösterilmektedir (Heinze, 2005). Ancak ne var ki yapılan kimi hataların ise öğretmenler için öğrenme maliyeti oldukça yüksek görünmektedir. Zira yapılan hataların etki boyutu hatanın türüne, kime karşı ve nerede yapıldığına bağlı olarak değişmektedir. Örnek olayların bazılarında geçtiği üzere kimi öğretmen hataları bazı öğrencilerin eğitim hayatının sonlanmasına dahi yol açabilmektedir. Söz konusu insan hayatı olduğundan dolayı öğretmenlerin bu süreçte telafisi zor hatalar işlemesinin bedeli öğrenci açısından oldukça ağır olabilmektedir. Bundan dolayı iyi bir pedagojik yetkinlikle öğretmenlerin göreve başlaması, mesleki yeterlilikler çerçevesinde öğretmen eğitimlerinin sürdürülmesi oldukça önemli durmaktadır (Bektaş, Aydın ve Ayvaz, 2015; Eskicumal1, 2002; Kahyaoğlu, Özbek ve Özgen, 2007). Bunun yanında yaptığı hatanın farkında olmak, kendine özeleştiri sunmak ve hatadan geri adım atarak öğrenciyi kazanma yönünde girişimlerde bulunmak ise öğretmenler açısından oldukça değerli mesleki kazanımlar olarak ele alınmalıdır.

Araştırma bulguları büyük ölçüde öğretmenlerin öğrencilerine yönelik yaptıkları hatalar ile sınırlıdır. Bu hatalar daha çok, öğrenciyi diğer arkadaşları önünde rencide etme, küçük düşürme, öğrenciye hakaret etme, bağırma veya çeşitli şeylerle (not vb.) tehdit etme, şiddet uygulama, bir şeylerden mahrum bırakma, özgüvenlerini kırıcı davranışlarda bulunma gibi eylemleri içermektedir. Ancak mesleki hatalar sadece öğrencilerle sınırlı olmayıp öğretmenlerin meslektaşlarına, velilere, okul idaresine veya diğer okul paydaşlarına yönelik yaptıkları hatalar da söz konusu olabilmektedir. Sonuç olarak öğretmenlerin farklı türde, zamanda ve okulda mesleki hatalar yaptıkları ve bu hatalarından mesleki öğrenme sağlayarak ve deneyim elde ettikleri görülmektedir ancak bu öğrenmenin maliyetli (insan kaynağına zarar verme vb. yönden) bir öğrenme türü olduğu da görülmektedir.

Öğretmenlerin yaptıkları mesleki hataların ardından kendi eylemlerini sorgulamaları ve kendilerine özeleştiri yaparak hatalarını telafi etme yönünde girişimde bulunmaları hataya ve öğrencilerdeki olumsuz etkilerine yönelik önemli bir farkındalıktır. Ayrıca bunun yanında öğretmenlerin çoğunun günümüzde benzer hatalardan kaçındıklarını dile getirmeleri ise geçmişte tecrübe ettikleri durumlardan dolayı mesleki öğrenme sağladıkları ve bu yönde kazanım elde etikleri de anlaşılmaktadır. Araştırma bulguları öğretmenlerin yaptıkları ve etkisi büyük en önemli mesleki hataların daha çok mesleğin ilk yıllarında, pedagojik yetersizlikten, öğrencilerle, okul idaresi ve velilerle etkili iletişim kuramamaktan, tecrübesizlikten kaynaklandığını göstermektedir. Özellikle velilerle kurulacak etkili iletişimin öğretmenlerin ve okul yöneticilerinin işlerini kolaylaştırdığ1 görülmektedir (Çalışkan ve Ayık, 2015). Bu durum neticede öğretmenlerin sahip olması gereken mesleki yeterliklere ve öğretmen eğitimine kadar uzanmaktadır. Dolayısıyla öğretmen eğitimlerinin ciddi şekilde düzenlenmesi, eksik noktalarının belirlenerek giderilmesi, çeşitli senaryolar veya gerçek olaylar üzerinden oluşabilecek durumlara ilişkin eylem planlarının öğretmen adaylarına kazandırılması ve en önemlisi etkili bir iletişim dilinin mesleğin olmazsa olmazı olduğuna yönelik farkındalık kazandırılması sunulabilecek çeşitli öneriler arasında yer alabilir. Ayrıca farklı bir öneri olarak öğretmenlerin yaptıkları meslek hataları öğrencilerin gözünden ele alınabilir ve öğrencilerle yapılacak farklı araştırmalarla karşılaştırmalı bir çalışma yapılabilir.

$\mathrm{Bu}$ araştırma kendi içinde çeşitli sınırlılıklar taşımaktadır. Araştırmada maksimum çeşitlilik örnekleme yöntemi kullanılmış ancak il bazında sadece üç şehirden (Ankara, İstanbul ve Düzce) veriler elde edilmiştir. Bu durum çeşitliliğin şehir ve coğrafi bölge yönünden sınırlı kalmasına yol açmıştır. Diğer sınırlılık ise örneklem grubu içinde sadece bir tane okul yöneticisi bulunmasıdır. $\mathrm{Bu}$ durum da çeşitliliği sınırlandırmaktadır. Farklı çalışmalarda bu çeşitlilik daha zengin hale getirilebilir. 


\section{Kaynaklar}

Akpınar, B. ve Akdoğan, S. (2010). Negatif bilgi kavramı: Hata ve başarısızlıklardan öğrenme. Batı Anadolu Eğitim Bilimleri Dergisi (BAED), 1(1), 14-22.

Atıc1, M. (2001). Öğretmen yetkinliği. Kuram ve Uygulamada Ĕgitim Yönetimi, 195-209.

Bektaş, M., Aydın, E. ve Ayvaz, A. (2015). Sınıf öğretmeni adaylarının gelecekteki mesleki yeterliklerine yönelik görüşleri. Sakarya University Journal of Education, 5(2), 174-192.

Çalışkan, N. ve Ayık, A. (2015). Okul aile birliği ve velilerle iletişim. Ahi Evran Üniversitesi Sosyal Bilimler Enstitüsü Dergisi, 1(2), 69-82.

Duman, B. (2010). Öğrenme-öğretme sürecindeki hata, yanılsama ve yanıltmacalara ilişkin öğrenci görüşleri. Muğla Üniversitesi Sosyal Bilimler Enstitüsü Dergisi, 25, 15-40.

Eskicumal1, A. (2002). Eğitim, öğretim ve öğretmenlik mesleği. Y. Özden (Ed.), Öğretmenlik Mesleğine Giriş içinde. Ankara: Pegem A Yayıncılık.

Gartmeier, M., Bauer, J., Gruber, H. and Heid, H. (2008). Negative knowledge: Understanding professional learning and expertise (Research report no:30). Regensburg: University of Regensburg.

Heinze, A. (2005). Mistake-handling activities in the mathematics classroom. H. L. Chick and J. L. Vincent (Eds.), Proceedings of the 29th Conference of the International Group for the Psychology of Mathematics Education (pp. 105-112) içinde. Melbourne: PME.

Kahyaoğlu, M., Özbek, R. ve Özgen, N. (2007). Öğretmen adaylarının öğretmenlik mesleğine yönelik görüşlerinin değerlendirilmesi. Afyon Kocatepe Üniversitesi Sosyal Bilimler Dergisi, 9(2), 221-232.

Kozikoğlu, İ. ve Senemoğlu, N. (2018). Mesleğe yeni başlayan öğretmenlerin karşılaştıkları güçlükler:

Nitel bir çözümleme. Eğitimde Nitel Araştırmalar Dergisi - ENAD, 6(3), 341-371.

McGregor, J. (2006). How failure breeds success. Business Week, 42-52.

Merriam, S. B. (2013). Nitel araştırma: Desen ve uygulama için bir rehber. (Selahattin Turan, Çev. Ed.). Ankara: Nobel Yayıncilık.

Miles, M.B. and Huberman, A.M. (1994). Qualitative data analysis: An expanded sourcebook. CA: Sage Publications.

Millî Eğitim Bakanlığ1 . (2017). Öğretmenlik mesleği genel yeterlilikleri. MEB Öğretmen Yetiştirme ve Geliştirme Müdürlüğ̈̈: Ankara.

Orange, C. (2007). 25 biggest mistakes teachers make and how to avoid them. California: Corwin Press.

Oser, F. and Spychiger, M. (2005). Lernen ist schmerzhaft. Zur 'Iheurie des Negativen Wissens und zur Praxis der Fehlerkultur [Learning is painful. On the theory of negative knowledge and the practice of error culture]. Weinheim: Beltz.

Özer, B., Gelen, İ., Alkan-Hızlı, S., Çınar, G. ve Duran, V. (2016). The most common mistakes of teacher trainees' former teachers. Universal Journal of Educational Research, 4(5), 963-972. 
Patton, M. Q. (2014). Nitel araştırma ve değerlendirme yöntemleri. (M. Bütün ve S. B. Demir, Ed.). Ankara: Pegem Yayıncilı.

Rach, S., Ufer, S. and Heinze, A. (2013). Learning from errors: Effects of teachers training on students' attitudes towards and their individual use of errors. PNA, 8(1), 21-30.

Sarı, M. ve Altun, Y. (2015). Göreve yeni başlayan sınıf öğretmenlerinin karşılaştıkları sorunlar. Hacettepe Üniversitesi Eğitim Fakültesi Dergisi, 30(1), 213-226.

Schoemaker, P. (2011). Brilliant mistakes: Finding success on the far side of failure. Philadelphia: Wharton Digital Press.

Sezer, Ş. (2018). Öğretmenlerin sınıf yönetimi tutumlarının öğrencilerin gelişimi üzerindeki etkileri: Fenomenolojik bir çözümleme. Hacettepe Üniversitesi Eğitim Fakültesi Dergisi, 33(2), 534549.

Shallenberger, D. (2015). Learning from our mistakes: International educators reflect. The Interdisciplinary Journal of Study Abroad, 26, 248-263.

Tjosvold, D., Yu, Z. and Hui, C. (2004). Team learning from mistakes: The contribution of cooperative goals and problem solving. Journal of Management Studies, 41(7), 1223-1245.

Ullsperger, M. (2008). Minding mistakes: How the brain monitors errors and learns from goofs. Scientific American, 19, 52-59.

Yariv, A. (2011). Deterioration in teachers' performance: Causes and some remedies. World Journal of Education, 1(1), 81-91.

Yıldırım, A. ve Şimşek, H. (2013). Sosyal bilimlerde nitel araştırma yöntemleri. Ankara: Seçkin Yayınlar1. 


\section{Extended Abstract}

\section{Introduction}

In many occupations that require expertise, people can make various professional mistakes until they reach a certain level of competence. These mistakes can sometimes be caused by insufficiency of professional skills and competence, and sometimes from work itself, person and environment. However, as a job requiring professionalism, the negative effects of professional mistakes made in the teaching profession may be more than other professions. Because the focus of this profession is the people prepared for society and life. Some of the mistakes made by teachers, especially in this learning journey, may have difficult effects to compensate because teachers are considered to be the most interacted, socialized, pedagogical, and most influential people in education (Özer, Gelen, Alkan, Çınar and Duran, 2016).

Mistakes made by teachers may vary according to a person, school or community. Some of the mistakes can be directed to the student, some to the colleagues, managers, parents and other stakeholders. Various studies conducted in the literature show that there may be a wide range of teacher mistakes. In addition, insensitivity, lack of competence in the field, poor leadership and management skills, behaviors to be ethical, to make inappropriate reactions, to make false accusations etc. may be added (Orange, 2007). There are several reasons for these mistakes. Among these reasons, teacher's low pedagogical competence level, weak leadership and management skills, not using effective communication language, dislike the profession, inexperience, various prejudices, excessive workload, stress, personality traits of the teacher, school management, environment and triggers from the family etc. can be mentioned. Although occupational mistakes originating from personal characteristics, social environment and the workplace worked are inevitable, there are many studies in the literature arguing that these mistakes are acquired (Schoemaker, 2011; McGregor, 2006; Ulssperger, 2008).

\section{Method}

This study was designed according to the holistic single case study design of qualitative research methods. In this design, factors related to a situation (environments, individuals, events, processes, etc.) are investigated in depth with a holistic approach and the focus is on how these factors affect the situation. The holistic single-state pattern is one of the types of patterns used to test, verify or refute a variety of theories that have already been proposed. In addition, in the study of extreme, contradictory or peculiar situations that do not comply with the general standards, a holistic single case design is preferred (Yıldırım and Şimşek, 2013).

As the focus of this study was on professional mistakes and experiences, the data were collected from individuals who have been teaching for a certain period of time. Research data were obtained from a total of 38 teachers working in different schools and cities with various branches and seniority. 16 of the participating teachers are male and 22 of them are female. In terms of branches, there are 6 primary school teachers, 1 teacher of Physics, 1 teacher of History, 4 teachers of Mathematics, 2 teachers of Biology, 1 teacher of German Language, 2 teachers of English Language, 2 teachers of Religious Culture, 2 teachers of Science and 2 teachers of Turkish Language. In addition, 1 Social Studies teacher, 3 electrical teachers, 2 technology-design teachers, 1 Physical Education teacher, 1 philosophy teacher, 1 Clothing Technologies teacher, 3 preschool teachers, 2 literature teachers and 1 advisory teacher are included in the study group.

The data of the study were obtained through the form prepared by the researcher. In the form, the following questions were asked to the participating teachers. 
-What are the mistakes you made in your professional life that you cannot forget? Describe this mistake or mistakes in detail before, during and after the event. (Answer this main question by thinking around these sub questions)

Sub-questions: What kind of school were you working when you made mistakes? How were the working conditions? What was the location of the school, the environment and the parents? How many years have you been a teacher? Who did you make the mistake against? Have you or anyone else suffered material or moral damage from these mistakes? What did you learn from these mistakes? What has contributed to your professional life and professional development? Did it change you in a positive or negative way?

The data were collected in 2019 September-November period. Descriptive and content analysis techniques were preferred for data analysis. In the descriptive analysis, the data are interpreted around the predetermined themes and the striking expressions of the interviewed individuals are directly included.

\section{Results, Discussion and Conlusion}

The results of the research show that teachers make professional mistakes from time to time. Most of these errors occur in the first years of the profession. Behind the mistakes, there are often reasons such as inexperience and lack of pedagogical knowledge. Teachers regret the mistakes they made, but they also obtained various professional learning from these mistakes.

This study aims to reveal the various pedagogical effects of different professional mistakes that teachers make in their professional lives and to address these mistakes within the framework of teachers' professional learning and attainment. The mistakes made by the teachers and their experiences should not be considered as past events. This case and mistakes has a nostalgic aspect as well as a teaching side. It is seen that the independent events and mistakes made by teachers working in different branches and seniorities in different cities contribute to their professional learning and support their professional development. It is seen that similar factors are behind the emergence of various common negative experiences experienced by teachers. Pedagogical incompetence and inexperience are among the most powerful reasons that cause teachers to make mistake. Most of the professional mistakes are made mainly on communication and classroom management in the first years of the profession (Duman, 2010; Kozikoğlu and Senemoğlu, 2018). 